\title{
Algunas imágenes de Dios y teologías liberadoras dentro de la religiosidad popular latinoamericana*
}

\author{
Juan Pablo Espinosa Arce**
}

Recibido: 22 de octubre de 2017 • Aprobado: 29 de noviembre de 2017

\section{Resumen}

El presente artículo busca articular una reflexión en torno a la religiosidad popular latinoamericana, específicamente en relación a algunas imágenes de Dios y teologías liberadoras dentro de la experiencia latinoamericana. La mediación que se utilizará será la estética como racionalidad, metáfora y teología. A partir de los aportes de Enrique Dussel y otros autores latinoamericanos, se busca, en última instancia, hacer comprender cómo un discurso cristiano liberador conlleva, necesariamente, la profesión en un Dios que libera y hace justicia a los oprimidos. Una religiosidad popular, si busca ser liberadora, deberá celebrar a este Dios que permite el buen vivir de sus hijos e hijas.

Palabras clave: Enrique Dussel, teología de la liberación, estética, racionalidad, fiesta.

* Artículo de reflexión presentado en el I Coloquio de Filosofía de la Liberación, Universidad de Chile (agosto de 2017). DOI: http://dx.doi.org/10.15332/s2011-9771.2017.0002.04

** Chileno. Licenciado en Educación y Profesor de Religión y Filosofía por la Universidad Católica del Maule. Magíster (Licenciado Canónico) en Teología Fundamental por la Pontificia Universidad Católica de Chile. Ayudante de Cátedra en la Facultad de Teología de la Universidad Católica. Tutor Académico de la Comunidad Religiosa "Santa Cruz" de Santiago de Chile. Correo electrónico: jpespinosa@uc.cl 


\title{
Some images of God and liberating theologies within Latin American popular religiosity
}

\begin{abstract}
This article seeks to articulate a reflection on popular Latin American religiosity, specifically in relation to some images of God and liberating theologies within the Latin American experience. The mediation that will be used will be the aesthetics as rationality, metaphor and theology. From the contributions of Enrique Dussel and other Latin American authors, it is sought, ultimately, to understand how a liberating Christian discourse involves, necessarily, the profession in a God who liberates and does justice to the oppressed. A popular religiosity, if it seeks to be liberating, must celebrate this God who allows the good living of his sons and daughters.
\end{abstract}

Key words: Enrique Dussel, liberation theology, aesthetics, rationality, party.

\section{Algumas imagens de Deus e teologias libertadoras dentro da religiosidade popular latino-americana}

\section{Resumo}

O presente artigo busca articular uma reflexão sobre a religiosidade popular latino-americana, especificamente em relação com algumas imagens de Deus e teologias libertadoras dentro da experiência latino-americana. A mediação que se utilizará será a estética como racionalidade, metáfora e teologia. A partir dos aportes do Enrique Dussel e de outros autores latino-americanos, busca-se, em última instância, fazer compreender como um discurso cristão libertador implica, necessariamente, a profissão em um Deus que libera e faz justiça aos oprimidos. Uma religiosidade popular, se busca ser libertadora, deverá celebrar a este Deus que permite o bom viver de seus filhos e filhas.

Palavras-chave: Enrique Dussel, teologia da libertação, estética, racionalidade, festa. 


\section{Introducción}

El aporte específico del presente estudio proviene del mundo de la educación religiosa y filosófica y desde la teología. Las reflexiones que seguirán se enmarcan dentro de la teología latinoamericana, conocida también como teología de la liberación. Ya hemos realizado algunas contribuciones académicas en torno al tema de la teología de la liberación, y en esta ocasión, pretendemos rescatar los aportes específicamente teológicos de Enrique Dussel y de otros pensadores, en torno al tema de la estética dentro de la religiosidad popular latinoamericana. En virtud de nuestra procedencia teológica, la comprensión de la estética que proponemos en esta comunicación no es una teoría de la apreciación del arte, sino que asumimos la estética como una mediación racional para pensar un determinado discurso teológico que presenta una imagen de Dios específica. Es por ello que nuestro desarrollo sigue la pista de Gadamer (2006, pp. 55-62) cuando pone en relación la estética y la hermenéutica $y$, en el caso de los teólogos latinoamericanos, la hermenéutica a la luz de la praxis y la praxis como hermenéutica. Esta praxis, en concreto, es la forma histórica de la religiosidad popular.

Es por ello que nuestra tesis central se formula de la siguiente manera: asumir una determinada imagen de Dios implica desarrollar un discurso teológico y vivir una praxis creyente (religiosidad popular) que posee como base dicha imagen de Dios. Así, una imagen de Dios funcional al sistema de mercado crea una absolutización de ciertos comportamientos de marginación y opresión. Y, por el contrario, rescatar la imagen del Dios de la Biblia que se revela históricamente como amigo de los pobres, salvador de los sufrientes, liberador de los esclavos, representa construir una estética teológica, filosófica y cultural que da espacios a una renovada fraternidad, solidaridad y compromiso efectivo con los que sufren. Dichas vivencias altermundistas ${ }^{1}$ se concretizan en la religiosidad popular, entendida como espacio cultural de vivencia de lo religioso.

Para ello, seguiremos en nuestro desarrollo tres momentos: 1) indagar el estado de la cuestión estética en su relación específica con la hermenéutica y la teología, a la vez, de rescatar cuál es la interpretación que Enrique Dussel da a lo estético como racionalidad, 2) proponer, desde esta estética, una comprensión de la religiosidad popular tal y como la comprende la teología latinoamericana y, 3)

1 El altermundismo (también llamado altermundialismo) es un movimiento civil que aboga por un cambio en el sistema económico internacional y las injustas consecuencias del modelo de desarrollo económico actual. 
asumir dos imágenes específicas de Dios presentes en dicha teología, y que están también presentes en el pensamiento de Dussel: el Dios Padre del Hijo manifestado al mundo, y el Siervo de Yahvé de Isaías que la comunidad cristiana primitiva identificó con Jesucristo y que es imagen y paradigma del pueblo crucificado y resucitado.

\section{Estado de la cuestión: la estética como mediación racional de la teología}

El tema de la belleza en la teología no es nuevo. Desde san Agustín vemos cómo hay una centralidad en el pulchrum como manifestación de la perfección de Dios a partir de la cristianización de los planteamientos filosóficos de Platón. Lo bello para Agustín tiene que ver con una sensibilidad interior para reconocer la perfección que en última instancia se encuentra en la realidad intangible (Horn, 2012).

En la teología del siglo XX, por su parte, encontramos los trabajos del teólogo suizo Hans Urs Von Balthasar quien vuelve sobre los temas de la forma -Gestalty de la percepción de la misma. Para Balthasar -y para todo el cristianismo- la forma o figura es Jesús de Nazaret en quien Dios ha hablado de manera radical al mundo (Col 1,15; Jn 1,14; Heb 1,1-2). Y esta forma se percibe desde la racionalidad estética como apreciación de la belleza de la misma. Así, Balthasar (2001) reconoce que en dicha Palabra de Dios revelada existe un elemento estético (p. 121). Y más específica, dicho componente estético y de belleza tiene su concentración en el acontecimiento de la Encarnación. En palabras de Balthasar:

En la medida en que la economía de la gracia lo consiente (que Dios se haya revelado) y en la medida en que se levanta el velo (revelar) que cubre el rostro del misterio de Cristo, la contemplación cristiana es capaz de admirar la sobre-sabiduría, la sobre-verdad, la sobre-belleza, en las autoenajenaciones del amor divino (p. 123).

Con estas indicaciones, estamos en posibilidad de afirmar que el componente estético de la teología tiene que ver con la apreciación del rostro de Dios en Jesucristo. La estética significa un reconocimiento del Dios que se ha aproximado al ser humano en la historia. Es un momento de revelación, de encuentro y de provocación del sentido humano y de la manera de comprender el Misterio de Dios. Esta interpretación de lo estético será la que nos acompañará en buena medida a lo largo de este desarrollo. 
En relación a esta revelación o manifestación de lo divino en la historia del hombre y del mundo, autores como César Carbullanca (2013) postulan que una teología de los signos de los tiempos y del discernimiento de la acción de Dios en lo historia implica también una mediación racional desde la estética. Este autor piensa la estética desde una comprensión lingüística -por ello habla de metáforaque busca recuperar la imaginación poética, las transformaciones del lenguaje y el sentido del mito, como componente presente en la teología latinoamericana y presente fuertemente también en la religiosidad popular. A juicio del autor, el paso de una excesiva racionalidad metafísica a una comprensión estética de la realidad cultural y teológica "recupera teológicamente la alteridad, emergencia del sentido teológico y el ethos cultural que vio nacer los relatos relativos a una teología de los signos de los tiempos" (p. 193).

Con lo anterior, evidenciamos cómo Carbullanca está pensando desde un método lingüístico de carácter pragmático el cual busca recuperar el sentido original en que fueron desarrollados los distintos discursos teológicos, a la vez que piensa cuáles fueron las motivaciones para que determinada comunidad pensara y favoreciera tal o cual imagen de Dios. Esta mención -implícita- de lo pragmático, está también en la base de la estética dusseliana. Es por ello que Dussel (2014) habla de la pragmática originaria (p. 191), en cuanto revelación del rostro del otro, y más específico, del otro radical, es decir, del sujeto que ha sido convertido en objeto por las lógicas de dominación cualesquiera ellas sean. Esta dominación y esta cosificación del sujeto, también implican una estética, es decir, una forma de pensar - una metáfora diría Carbullanca- a Dios y al ser humano en relación con otros, consigo mismo, con el Creador y con la naturaleza.

En otras palabras, la pragmática originaria significa volver al origen histórico del núcleo fundante de la experiencia humana, a saber, el aproximarse, reconocer y hacerse parte del mundo del otro, sobre todo del otro pobre y marginado. Con ello, una estética tal y como la piensan Carbullanca y Dussel, representa una "lectura de Latinoamérica desde una nueva base epistemológica dejando sin habla los supuestos metafísicos mediante una retirada a la metáfora de los signos de los tiempos originaria" (Carbullanca, 2013, p. 193). Incluso para autores como Ricoeur (2006) "la teoría de los símbolos nos permitiría completar la de la metáfora" (p. 67).

Dussel también da un lugar de importancia al giro lingüístico propio de la filosofía y de la teología del último siglo. Por ello, considera que una de las transformaciones epistemológicas de la teología de la liberación se sustenta en el paso de un paradigma de la consciencia -que podemos identificar con lo 
metafísico- a un paradigma del lenguaje en relación a la praxis. Por ello, se habla de un círculo hermenéutico en la teología de la liberación, a saber, la íntima relación entre teoría y praxis y entre praxis y teoría. En palabras de Dussel (1997), "se ha transformado en un paradigma lingüístico, ya que en realidad no se pensaba la praxis sino se la veía, juzgaba y se decía obrar desde un diálogo lingüísticamente articulado" (p. 205).

El adiós a la metafísica propuesto por estos autores, se comprende como un dar espacio y permitir hablar a elementos antropológicos vinculados a la sensibilidad, a lo erótico, a lo poético, a la fiesta, a los silencios forzados, a las luchas cotidianas y cómo en ellas se evidencia también el surgimiento de nuevos relatos y de nuevas epistemologías. Por ello, reconocemos la urgencia de pensar la filosofía, la teología o la pedagogía escuchando el relato y la sabiduría de los pueblos latinoamericanos. Y no solo de ellos, ya que Dussel amplía la pragmática originaria a los pueblos del sur: África, Asia. En sus palabras: “el otro, el pobre, el oprimido, el latinoamericano, africano o asiático, la mujer violada o el niño alienado se avanza desafiante, interpelante, provocante desde un más allá (symbolon) del mundo" (Dussel, 2014, p. 191).

La estética dusseliana y la propia de la teología latinoamericana, de la cual participa el mismo Dussel, asume la construcción de una epistemología desde el sur latinoamericano, asiático y africano, desde las periferias y la marginalidad. Hay en la fe cristiana un reconocimiento de cómo la voz del Espíritu de Dios sopla con fuerza desde el sur. Con ello, reconocemos con Irarrázaval (2013) que están apareciendo con fuerza "teologías del sur" (p. 353). La teología, la filosofía, las ciencias sociales y humanas, han de constituir un pensamiento históricamente encarnado, que escucha el contexto en el que se desarrollan y que son capaces de rescatar el sentido originario -pragmática- de los relatos y de las comprensiones teológicas, humanas y sociales. Estas epistemologías del sur son contextuales, liberadoras, altermundistas, ya que asumen "sabidurías del pueblo creyente" (p. 353) que buscan y "se sienten convocadas por el Misterio de Dios y lo reconocen a través de los signos de los tiempos" (p. 363). Es ante todo una experiencia simbólica, emparentada íntimamente con el symbolon dusseliano.

Por ello, es que creemos que el symbolon dusseliano tiene mucho de teológico. La estética de la liberación en vistas a un análisis integral de la religiosidad popular debe considerar necesariamente lo simbólico como racionalidad. No hay vivencia popular de la fe si no es en referencia a lo simbólico. A propósito de ello, Irarrázaval (2000) considera que "lo que más sobresale es lo simbólico. Ello brota de la espiritualidad, sensibilidad e inteligencia del pueblo. Esto reconoce las 
huellas de Dios en una cotidianeidad que está preñada de trascendencia" (p. 179). Hay presencia simbólica en la población. En una familia pueden convivir hijos con una mentalidad científica y padres con una mentalidad mítica. Lo mítico no representa un pensamiento erróneo o sin fundamento, al contrario, favorece otra comprensión de Dios, otra estética, otra forma de entendernos en el mundo. Lo que favorece la comprensión simbólica es el

Dar mayor espacio a la sensibilidad y a la verdad. No aprisiona la manifestación de Dios. No es un lenguaje unívoco (como ocurre con el lenguaje conceptual) sino más bien polisémico. Esta riqueza de significados no da pie a la confusión; por el contrario, es una apertura a la manifestación del Misterio que tiene diversas significaciones (...) el lenguaje simbólico forma parte de la teología; claramente está presente en la reflexión que asume la perspectiva bíblica, y en la que dialoga con el pensar de cada pueblo creyente (pp. 190-191).

Cuando Irarrázaval expone la manifestación simbólica del lenguaje y de la realidad, está favoreciendo una vuelta a los fundamentos históricos de las experiencias populares. En el caso de Dussel, la vuelta de la estética se realiza teniendo como horizonte la experiencia semita, la cual le impacta fuertemente en su estadía en Israel. Ahora bien, cuando Dussel propone la estética y su relación fundante con la otredad (aproximarse) como racionalidad, está recuperando justamente esta tradición semita en cuanto a que en el otro acontece una revelación, una epifanía o un suceso apocalíptico.

En sus palabras, "el otro en su carnalidad es la palabra primera (dabár en hebreo: que es palabra y cosa real), significante idénticamente significado, contenido histórico y exterioridad, metáfora biográfica, la desnudez como develación revelante" (Dussel, 2014, p. 191). Con ello, y esta es continuación de nuestra tesis, una teología -y una filosofía- que dialoga con lo estético como racionalidad, debe recuperar el fundamento histórico del semita Jesús. Con eso, hay una urgencia por lo histórico y cultural (pragmática originaria), por el suelo que vio nacer los relatos y las experiencias eclesiales y de manifestación de religiosidad popular. Son experiencias simbólicas que son carnales, culturales, que emergen y convocan, que va dando espacio a otras racionalidades y discursos antropológicos y teológicos.

Es por lo tanto que junto a Recanati creemos que la religiosidad popular representa la fuente de una nueva racionalidad opuesta a la frialdad de los conceptos metafísicos y también a los que emanan de las lógicas de poder económico, social 
y también religioso. La sapiencialidad latinoamericana evidencia "la importancia otorgada a la experiencia y al testimonio religioso personal, la revalorización de lo místico, lo mágico y lo milagroso, el nuevo arraigo en las relaciones inmediatas de grupo, etc." (Recanati, 2014, s. p.). En la experiencia religiosa latinoamericana, se pueden evidenciar tres elementos fundamentales, a saber: 1) la importancia de la tierra, la cual es comprendida como Pacha Mama. Con ello, se puede evidenciar la necesidad de replantear el tema ecológico y la estética de nuestras relaciones con lo creado, 2) la capacidad de hacer síntesis entre diversos elementos de la vida cotidiana $\mathrm{y}, 3$ ) la relación con la identidad y la pertenencia a una tradición familiar y popular, sobre todo en la imagen -escatológica- de la fiesta.

A partir de estas breves anotaciones en las cuales hemos tratado de evidenciar que la comprensión de lo estético está ligada a lo hermenéutico, a la búsqueda de sentido en la relación con el otro, al discernimiento de lo pragmático como fuente de sentido, es que pasamos a revisar cuál es la comprensión de la Iglesia y de la teología latinoamericana de la religiosidad popular.

\section{La religiosidad popular como elemento integrador de la experiencia eclesial y teológica latinoamericana}

Si pudiéramos identificar una experiencia lo bastante arraigada en la experiencia latinoamericana, es la religiosidad popular. Autores como Jorge Gissi (2002) comentan que dentro del contenido de la identidad de América Latina es el catolicismo sincretizado. Gissi reconoce cómo nuestro continente, dentro del escenario mundial, es el continente que continúa siendo propiamente católico, experiencia religiosa que es tanto característica como única. Para Gissi, el catolicismo sincrético se comprende como el proceso por el cual "los indígenas fueron catolizados, el catolicismo europeo fue indigenizado y después africanizado" (p. 39).

A partir de este antecedente basal de la religiosidad popular, procedamos a definir lo que es la religiosidad popular. Seguiremos para ello la definición propuesta por los obispos del continente en la III Conferencia General del Episcopado Latinoamericano realizada en Puebla, México, en 1979. Allí se lee:

Por religión del pueblo, religiosidad popular o piedad popular, entendemos el conjunto de hondas creencias, selladas por Dios, de las actitudes básicas que de esas convicciones derivan y las expresiones que las manifiestan. Se trata de la forma o de la existencia cultural que la religión adopta en un pueblo determinado. La religión del pueblo 
latinoamericano, en su forma cultural más característica, es expresión de la fe católica. Es un catolicismo popular (Documento de Puebla, n. 444).

De la anterior definición, extraemos los siguientes elementos. En primer lugar, es una experiencia teológica y religiosa: se cree en el Dios revelado en Jesucristo, presente en la Escritura y en la Tradición y anunciado por la comunidad creyente. Posee una dimensión ética, en vistas a las actitudes básicas que el creyente vive en el tiempo y en el espacio.

También la mención de que la religiosidad popular constituye una experiencia cultural: la religión no se encuentra al margen de una cultura, y la cultura también es una creación religiosa. Hay una mutua interdependencia entre ambas. Y dentro de esta dimensión cultural encontramos las expresiones propias de la vivencia de lo religioso a nivel de lo popular. Estas expresiones manifiestan la estética propia de la religiosidad popular (imágenes de Dios como discurso, imaginería sagrada, cantos, colores, aromas, danzas, comidas, etc.).

Esta cultura es esencial porque, como sostiene el teólogo argentino Lucio Gera (2015):

La fe no puede normalmente ser recibida y mantenida por todos, por las amplias masas y las mayorías, si no es mediada a través de la propia cultura de aquellos a quienes se anuncia. Ahora bien, la substancia de la cultura es la religión. La fe cristiana, por lo tanto, ha de encarnarse en la religión del pueblo (p. 307).

Enrique Dussel también nos aporta algunas características sobre la religiosidad popular latinoamericana. Dussel identifica cinco características. Estos elementos vienen a fundamentar, a nuestro juicio, la estética de la liberación. Lo estético, como ya hemos aventurado, representa una experiencia tanto lingüística como artística. Las características que reseña Dussel (1986) son en primer lugar, la sacralización del tiempo: El tiempo, sostiene Dussel, está en el horizonte religioso. Por ejemplo: al iniciar el día realizar sobre el cuerpo la señal de la cruz, celebrar las fiestas religiosas en el año civil-litúrgico, la espera del carnaval, etc. Hay también un tiempo del pueblo, una historia y una tradición. También hay una centralidad de la vida y de la muerte como momentos especiales de la vida humana.

Luego, la mención de la sacralización del espacio por cuanto hay un lugar en el cual se vive el tiempo religioso. Dussel distingue entre el centro y la periferia. Ejemplos del espacio: procesiones, peregrinaciones, la manda al santo, los santuarios. Estos espacios tienen una fuerte tradición, en cuanto que son creados por 
una tradición y una experiencia fuerte de lo religioso. $Y$ también la presencia de la comida y la bebida en las fiestas religiosas. Junto con ello, la sacralización del ritmo la cual tiene que ver con la danza y la música. Hay en esto un fuerte sentido de la sensualidad y de lo corporal. La fe, en la religiosidad popular, se baila, se canta, se le hacen décimas y rimas. Los refranes populares tienen lugares fundamentales en la religiosidad popular.

Posteriormente, los destinatarios, categoría por la cual se comprende cómo la religiosidad popular es realizada por sujetos históricos y culturales y se dirige a sujetos históricos y culturales. Aquí encontramos el núcleo de nuestra propuesta, porque los destinatarios implican una determinada imagen de Dios que les hace sentido en las luchas populares y en la vida cotidiana. Nos limitaremos a enunciarlas y las desarrollaremos posteriormente. Dussel reconoce cuatro imágenes teológicas, a saber: 1) el Dios de los pobres que es el Padre eterno, 2) la Virgen María, más cercana al pueblo y que es vista como madre de la misericordia, 3) Jesucristo que es representado como el Niño Dios (el Manuelito en el foclore chileno; el niño de los Andes en Perú y Bolivia) y el Crucificado y, 4) los santos y patronos de las familias y de las comunidades y los difuntos, las ánimas y los espíritus de las religiones afrocatólicas.

Finalmente, el éthos de la religiosidad popular. En el éthos reconocemos dos tipos de teología: una que Dussel llama de la resignación (Dios lo quiso así, por algo será), y que es de los grupos de dominación. Y también encontramos la teología de la liberación que, consciente de la realidad de opresión (ver), la juzga a través de la mediación social y cultural y también teológica, bíblica, espiritual y magisterial, en vistas a un cambio efectivo de la dominación por la liberación.

Estas características fundamentan el "comportamiento religioso" (Gera, 2015, p. 299) del pueblo, en este caso, del latinoamericano, a la vez que subrayan el "conocimiento simbólico" (p. 307) propio de la experiencia estética de la religión del pueblo. A juicio de Lucio Gera:

Dicho sistema simbólico implica por cierto una representación inteligente de la realidad en la que ese pueblo se siente inmerso, pero no solamente un conjunto de conceptualizaciones objetivas de esa realidad, sino además la expresión de una consciencia y deseo de participación en el misterio del ser y de la vida (p. 307).

Esto, representa la lógica interna de la religiosidad popular y de la estética de la misma. Hay representaciones, imágenes, ritmos, movimientos, espacios y tiempos, imaginarios simbólicos y elementos que van configurando la experiencia popular de lo religioso en América Latina. 
Lo anterior representa también una ruptura epistemológica en cuanto que la vivencia concreta de la religiosidad popular supera los fríos conceptos metafísicos (Carbullanca) y expresa la fe en lo corporal, en lo sensual, en la vida, en la comida, en las alegrías y las tristezas. Por ahí pasa la racionalidad estética y teológica de la religiosidad popular. Los símbolos y conceptos de Dios son más holísticos, integrales e integradores de diferentes ámbitos de la vida humana, personal y social. Evangelizar desde un discurso creyente y social que asume estas prácticas cotidianas, favorecerá una hermenéutica del sentido más profundo de la persona humana, porque dichos discursos y prácticas les serán cercanas y posibilitarán una vivencia liberadora de la vida y de la propia fe. Esto además, va contra la falsa idea de que la religión ya no tiene un lugar relevante en la vida humana. América Latina así lo ha demostrado.

Esta nueva hermenéutica, lingüística, teología y estética, es definida por Lucio Gera (2015) como una "mediación poética" (p. 308), es decir, la conciencia de que

La simbólica religiosa se forma a partir de las imágenes cosmológicas que brinda la naturaleza, como también de la experiencia familiar y social en las relaciones humanas (...) a través de la poesía como de la metafísica, la imagen cosmológica se torna percepción ontológica y religiosa. No hay religión sin poesía (308).

En ello, hacemos eco de las palabras de Diego Irarrázaval que sostiene que la estética de la religiosidad popular andina se basa en un compartir estético. En sus palabras, el mundo andino

Tiene sus modos de recrear simbólicamente la realidad, de nombrar los acontecimientos mediante la danza, la música, la tradición oral, la religiosidad, los gestos de amor, el juego, la artesanía, las fiestas. Todo esto y mucho más ocurre en la elaboración y el compartir estético. Son modos de sentir, de comunicar, recrear la realidad cotidiana: y ellos son generados por la gente común y sus portavoces (1999, p. 46).

Hasta aquí hemos visto con Dussel, Gera y los demás autores que la religión precisa una mediación poética. Y dicha poética tiene que ver con una est-ética y con una ética. Las tres realidades están relacionadas por el denominador común éthos, la cultura e idiosincrasia que recepciona la religión y le da un cariz distinto, que en el caso de América Latina está marcada por el sello de la opresión y la liberación. A partir de ello, queremos volver a rastrear en la teología de los autores que estamos estudiando algunas imágenes y aportes de la manera de 
fundamentar cómo una estética liberadora da sentido a la teología y a la vivencia eclesial de la religiosidad popular latinoamericana.

\section{Algunas imágenes liberadoras de Dios en la teología de la liberación latinoamericana como estética de la liberación}

Hemos visto con Dussel, Gera y los demás autores que la religión precisa una mediación poética. Y dicha poética tiene que ver con una estética y con una ética. Las tres realidades están relacionadas por el denominador común éthos, la cultura e idiosincrasia que recepciona la religión y le da un cariz distinto, que en el caso de América Latina está marcada por el sello de la opresión y la liberación. A partir de ello, queremos volver a rastrear en la teología de Dussel algunas imágenes y aportes Dios de manera de fundamentar una estética liberadora.

\subsection{Dios Padre de Jesucristo es el Dios de la vida celebrada}

En su artículo de 1977, Enrique Dussel plantea que el tema central del discurso teológico cristiano es el "Dios otro y creador" (p. 185), el cual es trinitario (Padre, Hijo y Espíritu), y que la primera afirmación es que “Dios es Padre y por ello su Verbo y nosotros sus hijos" (p. 185). Esta afirmación teológica está en la base de la tesis pedagógica de la relación padre-hijo que aborda Dussel de manera desarrollada en su Filosofía de la liberación. En primer lugar, pasaremos a presentar lo negativo o la forma de dominación de la relación filial-pedagógica -fetiche-para luego mostrar cómo su dimensión liberadora fundamenta una forma de hablar de Dios -teología- desde una determinada imagen de Él -estética-.

La relación del Dios Padre con el Dios Hijo revelada históricamente, representa el núcleo fundante de la experiencia cristiana. En cambio, en las culturas actuales el hijo -con minúscula- es asesinado por las gerontocracias -o el gobierno de los viejos-, por las burocracias -o las estructuras habitualmente administrativas- y también por los sistemas ideológicos -o la comunicación y las formas de educación-. En palabras de Dussel (1977), “el asesinato de la juventud, de lo nuevo, de la cultura popular tiene iguales asesinos: es el padre o el Estado o la institución autoritaria, dominadora o castradora" (p. 189).

Frente a este momento fetichista, se vuelve sobre el fundamento de la fe, a saber que Dios es Padre misericordioso que salva al pobre, salvación que acontece 
de manera suprema en la resurrección de Jesucristo, el pobre y justo por excelencia. Es el Dios de la vida que se opone críticamente a las formas de legitimación de la muerte (Estado, estructuras ideológicas, educación alienante). En palabras de Dussel (1997):

El Dios de la vida comunica esa vida y constituye el Reino de Dios, desde ahora y desde aquí. Pero dicha vida divina presupone, como el milagro de la creación, la vida humana como vida, en su producción, reproducción y desarrollo (p. 208).

Y la religiosidad popular debe ser una fuente constante de vida y de revitalización del tiempo y de las formas de bien-estar. En la religiosidad latinoamericana se une el tiempo humano y el tiempo de Dios. En ella la Vida en abundancia (Jn 10,10) se comunica graciosa y creativamente a la vida humana. Esto acontece, teológicamente, como fuerza del Espíritu de Jesús que permite recrear nuestras relaciones con nosotros mismos, con los otros, con Dios y con el medio ambiente. Por ello, la religiosidad popular latinoamericana tiene una relación tan estrecha con la tierra, con la madre tierra -sacralización del espacio-, porque en la tierra, en la experiencia de mundo e historia, se puede hacer experiencia de Dios. Por ello Irarrázaval (2013) sostiene que

La reflexión trascendente es relevante cuando ella es llevada a cabo a partir del corazón y desde los itinerarios humanos. En otras palabras, conviene tomar distancia de la erudición reacia a las emociones y a las transformaciones de cada día (pp. 33-34).

Con ello, la estética de la liberación es una que apuesta por el bienestar, por el sano convivir y por la armonía entre los seres humanos con Dios y con el medio que los acoge. Incluso podría abrirse una nueva veta de reflexión pensando, por ejemplo, qué significa el paso de un paradigma egocéntrico o egológico a uno ecocéntrico o ecológico. Si la estética asume la belleza, lo poético, lo metafórico, lo lingüístico, lo corporal, la sensualidad, en definitiva, la vida, una estética de la liberación en clave cristiana debe pasar necesariamente por asumir a Dios como el liberador de la muerte y de las estructuras de opresión e injusticia. Pero eso será para otra ocasión.

Creemos que este bien-vivir y la vida ofrecida por el Dios de Jesucristo, que es Padre y liberador de los pobres, se actualiza creativamente en la experiencia de la fiesta. La religiosidad popular es el tiempo del festejo, de la distensión, de lo lúdico, de la música, la danza, la comida y la bebida. Nuestros pueblos latinoamericanos supieron realizar una admirable síntesis entre la doctrina cristiana 
que provenía de Europa y sus formas autóctonas de encarar la vida a través de lo artístico, sus cosmovisiones e imaginarios. Dussel (2014) coloca acentos en la fiesta como expresión de la liberación. Así nos dice que:

El culto al Otro es la liberación misma. La fiesta del Otro es la alegría de la misma liberación. Por ello, nos dice Rosenzweig, los pueblos solo festejan y recuerdan los tiempos de su liberación; jamás se festejan las conquistas sobre otros pueblos. La fiesta de la liberación de los pueblos que cantan, bailan, corren, saltan, exaltan en alegría, son las fiestas de la salida de la prisión de la opresión. La fiesta política de los hermanos que crean la patria nueva; la fiesta erótica de la pareja que encuentra el orgasmo plenificante en el mutuo servicio desenajenante; la fiesta pedagógica de los jóvenes de la rebelión juvenil; cuando parecieran que ya tocan con la mano un mundo más justo, más humano en el cual puedan entrar sin ser reprimidos (p. 168).

La otredad dusselina se va articulando en relaciones con los otros -pueblos, hermanos, pareja, jóvenes-, pero también con el Otro, por ello habla de culto, y al finalizar este apartado dirá que "la fiesta del pueblo que se libera es la fiesta infinita, inconmensurable, la que mida toda otra alegría y la que permite seguir viviendo. Es un derramarse sobre la historia de la Alegría (con mayúscula) del Absoluto (con mayúscula)" (p. 168). Por ello en la fiesta hay presencia de Vida, de Dios y de una esperanza que abre un futuro en fraternidad. Hay un código en la celebración de la fiesta, porque ella, la fiesta, es una forma auténtica de la vida humana. Autores como Otto Maduro (1999) comentan que

En cierto sentido, la vida humana gira alrededor de la fiesta, se mueve en pos de la celebración. Nos esforzamos de sol a sol por lograr aquello que le dé alimento y sentido a la vida y que, por ende, merezca ser festejado gozosamente en compañía de nuestra gente querida: trabajo, amor, comida, hogar, salud, libertad, paz, tiempo para descansar, jugar y disfrutar la amistad gratuita (p. 11).

La fiesta es la ampliación de un horizonte vital y epistémico que asume lo gratuito como experiencia originaria. Es más, la misma teología afirma que el Dios creador es ante todo el Padre lleno de gracia (gratuidad) que convida a su Hijo y a sus hijos la gracia como signo de su presencia salvadora. Por ende, cuando el pueblo celebra sus fiestas de vida y de muerte, sus procesiones y romerías, sus cantos a lo divino y a lo humano, está invitando a que Dios tome asiento en 
sus fiestas. El Dios cristiano tal y como es pensado en América Latina es el Dios de la vida celebrada. Como recuerda el teólogo chileno Ronaldo Muñoz (1986):

Para nuestros hermanos de las comunidades populares, Dios no está por encima del pueblo de los pobres, imponiéndole esta situación de miseria y de muerte (...) Por el contrario, Dios está en la historia misma de los oprimidos, Dios está muy encarnado en el pueblo, en las experiencias personales y colectivas. Dios es el gran afectado por la situación que sufre el pueblo (p. 140).

Por ello, una religiosidad popular auténticamente evangélica no muestra una imagen de Dios que oprime, al contrario, es el Dios liberador que celebra la vida. En ello, se cumple la máxima de los Padres de la Iglesia de que la gloria de Dios es que el hombre viva, y nosotros agregamos que viva bien. Volvemos a la lógica del bien-estar como experiencia lúdica y festiva, estética y ética, ecológica y antropológica, teológica y eclesial. Por ello es necesario, finalmente, pensar la fiesta como episteme, ya que si seguimos el planteamiento de Maduro (1999),

Podríamos imaginarnos el conocimiento humano como un intento de elaborar mapas para la fiesta: suerte de guías para tratar de encontrar y abrir caminos que nos lleven de vuelta a la buena vida y que merezca y facilite ser frecuentemente festejada con alegría, placer y gusto (p. 13).

De esta manera, la fiesta funcionará como "test" (Trigo, 2013, p. 188) en cuanto que ella es medida adecuada para ver si la vida -que es sagrada- es celebrada como fiesta sagrada. La fiesta acontece y Dios acontece en la celebración. Por ello, comenta Pedro Trigo,

La fiesta es un símbolo de lo absoluto, del reinado de Dios. Y solo se accede a ella si se ha aceptado el reinado de Dios, la semilla de vida filial y fraterna que Él deposita en el corazón de cada ser humano. En la fiesta se celebra simplemente esta vida humana que fluye por los mil canales de la cotidianidad (p. 189).

\subsection{Jesucristo, imagen del Siervo de Yahvé, paradigma de comprensión del pueblo sufriente y resucitado}

En este último apartado, presentamos una imagen cristológica clásica dentro de la teología latinoamericana, a saber, Jesucristo como imagen del Siervo de Yahvé 
que es paradigma de comprensión del pueblo sufriente y resucitado por el Dios de la Vida. La estética de la liberación se mueve entre estos dos momentos, la opresión y la salvación, la muerte y la resurrección.

El Siervo de Yahvé es una imagen teológica que encontramos en la literatura profética de Isaías, y que el profeta y su comunidad aplicaron a un personaje misterioso que intercede por el pueblo (Is 52,13-53,12). El texto bíblico nos muestra a un hombre "desfigurado", alguien que "no tenía el aspecto de un hombre ni apariencia humana" (Is 52,14), uno "sin apariencia ni presencia; no tenía aspecto que pudiésemos estimar" (Is 53,2). Del Siervo se dice que es un "despreciado, marginado, hombre doliente y enfermizo, como de taparse el rostro para no verle. Despreciable, un Don Nadie" (Is 54,3). Es uno sobre el cual Yahvé descarga todas las dolencias y los pecados del pueblo (Is 53,10). Con esto no encontramos belleza, gracia, deseo de contemplar. Pareciera ser que la belleza como canon de lo correcto, de lo pulcro o lo perfecto no tiene lugar en este hombre sin nombre. Pero, y es aquí donde acontece la paradoja, este hombre despreciable es uno que logra la salvación para sí y para todos. Así, al final del Cántico leemos que él "vera descendencia, alargará sus días... por las fatigas de su alma, verá luz, se saciará. Por su conocimiento justificará mi Siervo a muchos... él llevó el pecado de muchos e intercedió por los rebeldes" (Is 54,11-12).

Este texto de Isaías, la comunidad cristiana lo aplicó a la persona de Jesús (cf. Hech 8,26-40). La pasión de Cristo se confronta con los dolores del Siervo. La imagen deformada del varón de dolores posee una belleza que es paradójica. Es más bien una imagen llena de fealdad, pero aun así es una proyección de la gracia/ salvación que Él logra en virtud de sus sufrimientos. Para el cristianismo la gracia se logra justamente en la Muerte y Resurrección de Jesús. El Misterio Pascual es la fuente perenne desde la cual brota toda la acción salvífica de Dios. Así, y si tenemos en cuenta esta dimensión desinteresada de lo bello, entonces la gracia pura gratuidad-es belleza por excelencia, y su glorioso misterio resplandece y se derrama ante todo -inaferrable paradoja de Dios- en la fealdad del Crucificado.

Esta imagen teológica es asumida -implícitamente- por Dussel (2014) en su libro Filosofía de la liberación, cuando sostiene que:

La aparente fealdad del rostro del oprimido, el ajado rostro del campesino, la endurecida mano del obrero, la cara tosca de la mujer del pueblo (que no puede comprar la cosmética vigente), es el punto de partida de la estética de la liberación, porque es la interpelación que revela la belleza popular, única belleza no dominadora y liberadora de la belleza futura. El esteticismo es la imposición ideológica 
dominadora de la belleza vigente, de las culturas del centro y las clases oligárquicas. Es la ideología de la belleza fetichizada (p. 94).

Hay, por lo tanto, una estética paradójica que comienza en los márgenes de las grandes ciudades y sociedades humanas. Dussel habla del oprimido, del obrero, de la mujer del pueblo. Estos rostros son excluidos por las ideologías que encorsetan la belleza en determinados cánones, pero que son fetiche de un sistema de dominación. Y la teología latinoamericana ha comprendido cómo esos mismos rostros son prolongación histórica del rostro mutilado, golpeado, desfigurado del Siervo de Yahvé y del mismo Jesús de Nazaret. La muerte de Jesús es a causa del imperio y de las lógicas de poder de grupos que legitiman prácticas de exclusión. Y la suerte de los marginados del sur (Latinoamérica, África, Asia) es también causada por estos grupos que fetichizan la belleza. La salvación y la resurrección acontecen en lo paradójico y en la vida que se oculta tras la aparente fealdad del rostro del oprimido.

Las comunidades populares celebran la memoria del Dios crucificado y resucitado, y lo realizan de manera concreta, histórica e incluso pagando con sus propias vidas. Hay, por lo tanto, algo así como una estética martirial, una forma de actualizar comprometidamente la acción del Siervo de Yahvé. Pensemos por ejemplo en la vida y sacrificio de monseñor Óscar Romero en El Salvador, o de un André Jarlán en la población La Victoria de Santiago de Chile, de Ignacio Ellacuría S. J. en El Salvador, y en cientos de mujeres y hombres, jóvenes y niños anónimos que prolongan la belleza paradójica de Jesucristo muerto y resucitado. Hay una forma en la que el pueblo venera a sus héroes y personajes que fueron sentando las bases de una tradición y de una espiritualidad de la liberación. El martirio latinoamericano es imagen del martirio de Jesucristo. A propósito de Óscar Romero, el jesuita español Daniel Izuzquiza (2008) comprende al mártir latinoamericano como "cuerpo transfigurado" (p. 255). Hay, por lo tanto, una estética en el martirio cristiano que, teológicamente, ha sido inaugurado por el Mesías Jesús.

Romero es prolongación del Cuerpo golpeado de Jesucristo y en él reconocemos al Dios de la vida que opta por los pobres. Y la mención al cuerpo no es menor, ya que como hemos venido reflexionando, la estética de la religiosidad popular da mayor espacio a lo corporal, a lo vital, a las experiencias cotidianas, a una historia concreta de muerte y resurrección. Por ello Izuzquiza (2008) sostiene que Romero

Supo estar como pocos al lado de su pueblo y encarnar de manera contundente la opción de Dios por los pobres. Acercarnos a su experiencia 
espiritual y a su labor pastoral nos lleva a descubrir la centralidad del misterio del cuerpo de Cristo: en la fragilidad del pan y en la fragilidad del pueblo creyente oprimido, en la gloria del Señor y en la fuerza de la Iglesia (p. 256).

Y por el sacrificio de Cristo y de Romero, los pobres tienen esperanza de que la vida triunfa sobre la muerte. La estética de la liberación, a nuestro entender, pone acentos en la experiencia de resurrección cotidiana. Hay una relación interna entre la Cruz y la Resurrección, entre la esperanza y la utopía, entre la fiesta como recreación histórica de la fe en el Señor resucitado y las formas de humanización cotidianas. Por ello sostiene Kreti Sanhueza (2016) que

Los cristianos de Latinoamérica, definidos por la fe y seguimiento de Jesucristo, se preguntan por el significado de la muerte de Jesús en una realidad histórica marcada por el pecado de la pobreza y de la marginación, que exige conversión. Una manera de dar respuesta a los interrogantes y de anunciar a Jesucristo en el continente, ha sido y sigue siendo la perspectiva de justicia y de martirio (p. 195).

\section{Conclusiones}

La comprensión de lo estético que hemos propuesto en esta comunicación es una de corte lingüístico y hermenéutico. A pesar de que la teoría estética se basa, preferentemente, en la crítica de arte, creemos que pensar la misma en clave metafórica, poética, teológica y filosófica, nos permite construir una epistemología más amplia y más integradora de distintos sentidos de la vida humana. Y sostenemos ello porque la religiosidad popular latinoamericana está construida en base a distintas formas de convivencia cotidiana y de relaciones entre los seres humanos y de ellos con Dios. La experiencia popular latinoamericana representa una de las características propias de la identidad del continente. La fe cristiana, vivida sincréticamente en el continente, debe asumir un lugar social, histórico, político y cultural en favor de los marginados. Solo así será una auténtica religiosidad popular cristiana.

En esta religiosidad popular, Dussel sostiene que conviven imágenes de un dios (con minúscula) fetichizado que está anclado en grupos de dominación y de destrucción de la vida de los pobres. Y por el contrario, encontramos presencia de imágenes liberadoras de Dios que anuncian la vida y la justicia como formas 
de construcción de una sociedad más humana. Hemos rescatado dos de ellas, a saber, el Dios de la vida y el Siervo de Yahvé, en los cuales se reúnen las formas claves para comprender las expresiones liberadoras de la religiosidad popular latinoamericana.

En penúltimo lugar, consideramos que es necesario seguir pensando la religiosidad popular a partir de cuestiones puntuales, entre ellas el signo del martirio. América Latina conoce de historias de entrega, de derramamiento de sangre y de testimonio profético y apostólico de cientos de cristianos anónimos y otros conocidos, los cuales manifiestan al Dios de la vida. Hay una estética en el martirio, no solo como apreciación de una pintura, de música o de material audiovisual, sino como una contemplación de una forma de vivir y morir. Hay formas en las cuales la religiosidad popular se va encarnando en los distintos contextos y situaciones del continente. Sería interesante seguir abriendo caminos reflexivos y de celebración consciente y fructuosa de lo religioso en Latinoamérica.

Finalmente, el desafío de seguir construyendo puentes que permitan articular discursos y prácticas que den sentido al estar del ser humano en el mundo, un estar pletórico de sensaciones, de colores, formas, poesías, cuerpos, ritmos, comidas y danzas. En estas culturas tan diversas, los creyentes asumimos que Dios se ha hecho hombre, de manera que en esas formas culturales Él se nos revela como el Padre que libera a sus hijos de la muerte, del Creador de una vida nueva que destruye los ídolos de muerte, de un Dios que anuncia las buenas nuevas en lo cotidiano.

\section{Referencias}

Balthasar, H. (2001). Revelación y belleza. H. Balthasar Verbum Caro. Ensayos teológicos I. Madrid, España: Cristiandad, pp. 103-133.

Carbullanca Núñez, C. (2013). Signos de los tiempos y metáfora: Una estética de los signos de los tiempos. Veritas, (28), 191-220.

CELAM. (1979). III Conferencia General del Episcopado Latinoamericano. Declaración de Puebla. Conferencia realizada en Puebla, México.

Dussel, E. (1977). Supuestos histórico-filosóficos de la teología en América Latina. En Rosino Gibellini (ed.). La nueva frontera de la teología en América Latina. Salamanca, España: Sígueme, pp. 174-198.

Dussel, E. (1986). Religiosidad popular latinoamericana (hipótesis fundamentales). Cristianismo y sociedad, 88, 103-112. Recuperado de: http://enriquedussel.com/txt/ Textos_Articulos/166.1986.pdf 
Dussel, E. (1997). Teología de la liberación. Transformaciones de los supuestos epistemológicos. Theologica Xaveriana 47, pp. 203-214.

Dussel, E. (2014). Filosofía de la liberación. México D. F., México: Fondo de Cultura Económica.

Gadamer, H. (2006). Estética y hermenéutica. Madrid, España: Tecnos.

Gera, L. (2015). La teología argentina del pueblo. Edición preparada por Virginia Azcuy. Santiago de Chile, Chile: Centro Manuel Larraín-Universidad Alberto HurtadoUniversidad Católica de Chile.

Gissi, J. (2002). Psicología e identidad latinoamericana. Santiago de Chile, Chile: Ediciones Universidad Católica de Chile.

Horn, C. (2012). Agustín de Hipona: una introducción. Santiago de Chile, Chile: Colección IES.

Irarrázaval, D. (1999). Un cristianismo andino. Quito, Ecuador: Abya-Yala.

Irarrázaval, D. (2000). Símbolos y conceptos de Dios. Sociedad Chilena de Teología, X Jornada de la Sociedad Chilena de Teología. Talca, Chile: Contacto, pp. 177-195.

Irarrázaval, D. (2013). Indagación cristiana en los márgenes: un clamor latinoamericano. Santiago de Chile, Chile: Centro Manuel Larraín-Universidad Alberto HurtadoUniversidad Católica de Chile.

Izuzquiza, D. (2008). Enraizados en Jesucristo: ensayo de eclesiología radical. Santander, España: Sal Terrae.

Maduro, O. (1999). Mapas para la fiesta. Reflexiones latinoamericanas sobre la crisis y el conocimiento. Buenos Aires, Argentina: Centro Nueva Tierra.

Muñoz, R. (1986). Dios de los cristianos. Santiago de Chile, Chile: Paulinas.

Trigo, P. (2013). Relaciones humanizadoras: un imaginario alternativo. Santiago de Chile: Centro Manuel Larraín-Universidad Alberto Hurtado-Universidad Católica de Chile.

Recanati, G. (2014). “La religiosidad popular latinoamericana: desde la otra lógica de la racionalidad sapiencial y hacia el pluralismo de creencias". Congreso Internacional "La libertad religiosa en el siglo XXI. Religión, Estado y Sociedad". Recuperado de: http://www.calir.org.ar/congreso2014/Ponencias/RECANATI. Lareligiosidadpopular.pdf

Ricoeur, P. (2006). Teoría de la interpretación. Discurso y excedente de sentido. México D. F., México: Siglo XXI Editores.

Sanhueza, K. (2016). Jesucristo, prototipo de justicia y martirio, a favor de los pobres y marginados. Cuestiones Teológicas 99, pp. 175-197. 